The Kurdish Tribes of the Ottoman Empire

Author(s): Mark Sykes

Source: The Journal of the Royal Anthropological Institute of Great Britain and Ireland, Vol. 38

(Jul. - Dec., 1908), pp. 451-486

Published by: Royal Anthropological Institute of Great Britain and Ireland

Stable URL: http://www.jstor.org/stable/2843309

Accessed: 07-11-2015 08:29 UTC

Your use of the JSTOR archive indicates your acceptance of the Terms \& Conditions of Use, available at http://www.jstor.org/page/ info/about/policies/terms.jsp

JSTOR is a not-for-profit service that helps scholars, researchers, and students discover, use, and build upon a wide range of content in a trusted digital archive. We use information technology and tools to increase productivity and facilitate new forms of scholarship. For more information about JSTOR, please contact support@jstor.org. 


\section{THE KURDISH TRIBES OF THE OTTOMAN EMPIRE.}

\section{By Mark SyKes.}

\section{Preface.}

THE materials collected in the ensuing pages are the results of about 7,500 miles of riding and innumerable conversations with policemen, muleteers, mullahs, chieftains, sheep drovers, horse dealers, carriers and other people capable of giving one first hand information. The results I fear are extremely meagre, but I hope they may prove of use to future travellers.

As hardly anything has been written on the subject in the English language heretofore, I have not been able to make a study of the Kurds from a bibliographical point of view. However, I trust that this will not detract from the interest of the work. I may add that I had among my servants on my last journey representatives from the three most important sections of the Kurds, so that I was able to obtain interpreters without any great difficulty, a matter of some importance amidst the conflicting dialects of the nomads and sedentary mountaineers.

In preparing the following list of the various tribes of the Kurdish race I have endeavoured to simplify the work of future students by marking down and cataloguing as many of the tribes as have come either directly or indirectly under my notice.

After various abortive attempts at setting them down in a manner comprehensible to any one but myself, I have decided for the purposes of this work to break up the regions inhabited by Kurds into six zones; to each of these zones a section of the catalogue is devoted, each section containing a separate enumeration. Thus in the alphabetical list a tribe will be found, as for instance the Merzigi 76B, section A. To find the position of the tribe the reader must look in zone A on the map for the number 76 ; he will find this number is connected to a chain of letters; the letter B in this chain will mark the spot where this tribe is to be found, in the catalogue he will find such particulars as I can supply under the number $76 \mathrm{~B}$ in the printed section $\mathrm{A}$.

Before closing this preface may I say that the zones marked on the map are not ethnological but merely a convenient form of grouping.

\section{SECTION A.}

\section{Introduction.}

I have chosen this zone as the first to be treated chiefly because the Kurds dwelling in it are apparently the descendants of those ancient Cordueni who 


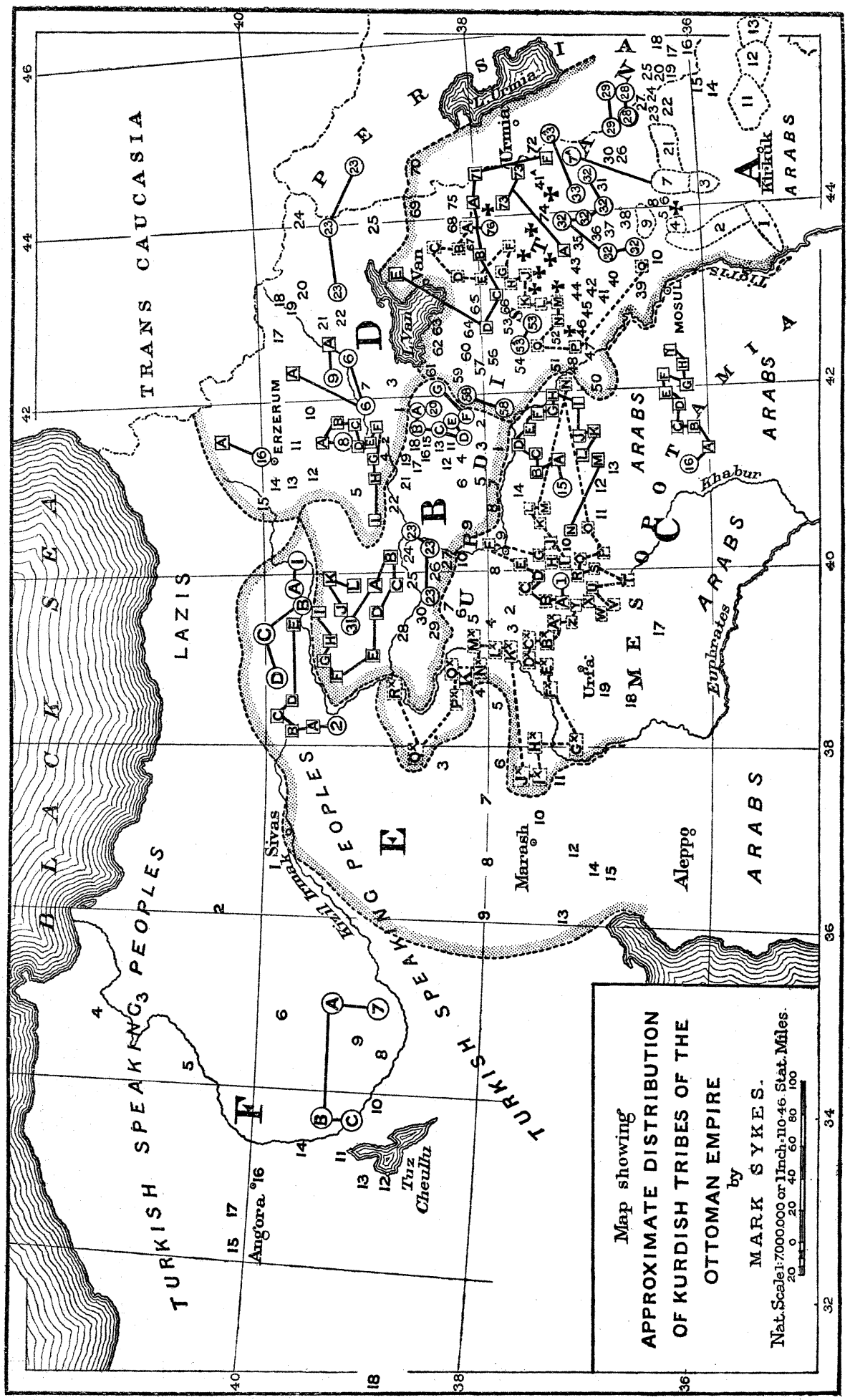


harassed Xenophon's retreat, and it is at least the theatre of the Kurds' first appearance on the stage of history. The densely populated zone is bounded on the north by Lake Van and the Armenian table land, on the west by the Tigris, and on the south by the plains of the Irak. I should imagine that the majority of its inhabitants are Kurds; however, we have a considerable foreign element in the plains, and it may be that some of the tribes mentioned in my list are not in fact Kurdish tribes but branches of other peoples who have become affiliated to the original mountain race. The foreign or at least non-Kurdish stocks may briefly be enumerated as the Arabo-Aramean population of Mossul, the pure Arameans as typified in the Nestorian and Jacobite Christians of Ain'Kawa, Akra, and Keui Sanjak, the Turkish peoples of Altyn Kiopru, Kerkuk and Erbil, and the Bedawin and Felahin Arabs on the banks of the Tigris and the plains eastward of Mossul.

The two peoples in this zone concerning whom I am completely in doubt are the Shabak No. 5 and Bejwan No. 10, and the Nestorian Christians of Hakkiari, Amadia and Zakho. The presence of the latter are denoted by a black . The question as to whether these Nestorian Christians of Hakkiari, who have a tribal organization, are indigenous Kurds or fugitive Christians of Aramean stock, is I think still open; several learned Kurdish ${ }^{1}$ notables are of opinion that the Nestorians of Hakkiari are Kurds who were converted to Christianity before the advent of $\mathrm{Al}$ Islam; on the other hand the Christian clergy are firmly convinced that this is not the case. Personally I suspect that both theories are in part true, and that when the Christians fled from Mossul and Irak, they took refuge with the Kurdish Christians of Hakkiari. This would make the Episcopal families new comers, just as many of the Kurdish Moslem chiefs trace their ancestry to Arabian Emirs. I regret that I was unable to obtain particulars as to the names of the Nestorian tribes, but it is to be hoped that the English Mission of the Archbishop of Canterbury will some day supply the deficiency.

With regard to the Kurds I think they may be divided into three classes. Class I.-Nos. 1, 2, 3, 4, 6, 7, 8, 9, 11, 12, 13, 14, 15, 16, 17, 18, 19, 20, 22, 23, 24, 25, who are the serni-nomads of the plains and southern hills; Class II, Nos, 21, $26,28,29,30,31,33,34,35,36,37,38,40,41 \mathrm{~A}, 44,48,52,53,53 \mathrm{~A}, 65,68,71_{\mathrm{A}}$, $71 \mathrm{~B}, 71 \mathrm{c}, 72,73$, who are the sedentary mountain tribes ; Class III, the semi-nomadic mountaineers comprising the remainder of the tribes with the exception of No. 50 .

As regards Class I the tribes catalogued under these figures are very similar to one another in habits and appearance. They are usually wealthy shepherds and only cultivate the ground for auxiliary purposes, though they frequently employ extraneous labour for agriculture and traffic in the produce thus obtained. They are expert smiths, weavers, and tent makers. Mentally they are far superior to the majority of Kurds, being apt to education, astute men of business and very indus-

1 The names of these gentlemen are:-Shaykh Nasreddin of Tillu; Shaykh Sadiq, of Neheri (now dead); Shaykh Hamid Pasha of Bashkala. 
trious. They live under the rule of hereditary tribal nobles, who are usually very quarrelsome, feuds and intertribal wars being common. These semi-nomads, who are known as the Baba or Baban Kurds, are noted for their chivalry, valour, and thieving proclivities ; they are all fine horsemen, and expert marksmen, having of late years discarded the lance and sword in favour of the rifle. I should imagine that the great cavalry armies of the Parthians were recruited from similar tribes, as the present evolutions and tactics of these people resemble those of the troops of Surenas as described in Plutarch's Life of Crassus. The patron Saint of the Baban Kurds is Khalid ibn Walid, whom they hold in great reverence, saying that he converted them from Paganism and the worship of fire.

All the tribes mentioned in this class are strictly orthodox Sunni Moslems.

During the months of October, November, December, January and February, they dwell in villages in the vicinity of the numbers as marked on the map; in March they go into tents and remain in them till early in June, at which period many families from each tribe migrate to the Wazna district with their flocks; during the summer months of July, Auguist and September, whether at Wazna or elsewhere they lay up their tents and construct bowers of green wood, in which they.live until the autumn nights grow chilly, when they return to their villages. Most of the noble families of the tribes in this class intermarry with the Arabs of Mesopotamia. However, their own women are strikingly beautiful and are allowed great freedom, many of the women can ride and shoot as well as the men, but undertake no manual labour beyond making butter and performing ordinary household duties.

Class II.-The sedentary mountaineers are completely distinct in custom and dress from the Baban Kurds. They are industrious agriculturists, and cultivate every available piece of ground in the vicinity of their villages, showing great capacity in diverting and damming streams, draining and ditching for the purpose of irrigating the terraced fields in the vicinity of their villages; these fields bear crops of barley, wheat, maize, rice, and excellent tobacco. They live under the rule of tribal chiefs and like the Baban Kurds are constantly at war with one another. The men carry rifles and daggers, and are active fighters and hunters. Each village has in its centre or near it a small double bastioned block-house or castle of hewn stone, where in times of war the people take refuge for purposes of defence. The intertribal battles are often extremely bloody, six or seven men killed out of a party of twenty being not uncommon.

As regards mode of life these Kurds, though sedentary, dweil in bowers erected on the flat roofs of their houses in summer. Like the Baban Kurds their women do not veil and are well treated. Some of the tribes in this category are of opinion that they were converted from Christianity, but most of them have Pagan traditions. Among them dwell a good many Jewish families who are never maltreated, but are not permitted to carry arms or engage in tribal feuds, consequently the Jews travel on trading expeditions from tribe to tribe whether the latter are friends or enemies. Nestorian Christians dwelling amongst these tribes are occasionally 
found living in a condition of vassalage, but as often as not share and own lands on an equal footing with the Moslem tribesmen.

Class III.-The remainder of the Kurds in section A are semi-nomadic mountaineers, being partly agriculturists, partly shepherds, and partly horse dealers; in dress they resemble Class II rather than Class I; they are of a thievish disposition, bloodthirsty, cowardly, and often cruel. Their women are ugly and hard worked, they usually ride donkeys or mules, and are extremely erratic in their movements. Speaking generally, they differ in appearance from Kurds of Class I and Class II, being big boned, heavily built men, of a very dark complexion. No one who saw them could imagine they were of the same origin. In their wanderings they frequently dispense with tents and shelter behind bales or reed screens. As a rule these semi-nomads are badly armed, poor in goods and of a cowardly nature. In religion they appear to have no fixed belief of any kind, and care very little for such matters, though they are counted as Moslems.

As regards No. 50, section A, the Miran, they are an exception to the above description, and the reader must look under their number for details concerning them. I would also note that in the South Irak, Wazna, and in the vicinity of Mossul, to be a nomad is considered noble; while in the mountains the word kochar, or shepherd, is synonymous with "savage," "ignorant" or "brutish."

1. Daudieh. 4,000 families. A warlike semi-nomadic tribe inhabiting the banks of the lower Zab. Noted swimmers, poor horsemen, Baban Kurds.

2. D'sdie. 5,000 families. A large tribe, partly composed of nomads and partly agriculturists. They intermarry freely with the Gibbur Arab women. This tribe has lost much of its wealth owing to locusts and drought. Their women are exceedingly handsome and affect a peculiar and distinctive dress, i.e., blue turbans like the men, and dark heavy garments, no colour or ornaments of any kind being worn. The men are good horsemen and agriculturists, the headquarters of the tribe are on the Sultan's farm in the Kara Chok Dagh. Baban Kurds.

3. Shaykh Bezeini. 4,000 families. A great and warlike tribe, turbulent and fierce. Noted robbers. Great horsemen. Very intelligent, make Martini Henry rifles. Live in villages in winter, dwell in tents in the vicinity of their villages in spring. After the harvest (June) proceed to Persian frontier with their flocks. Return in September, or later if the season is hot. Dress in Persian fashion. Baban Kurds.

4. Shaykhan. 500 families. Completely nomadic, wealthy shepherds, pasture flocks between Tigris and both Zabs. Avow no connection with Yezidis, ${ }^{1}$ and often camp with the Tai Arabs, with whom however they do not intermarry. Baban Kurds.

5. Shabak. 500 families. Sedentary, said to be Shias by some, others 1 See No. 46, Section A. 
affirm them to have a secret religion, others that they are Babis, others that they acknowledge a prophet named $B a b a$.

6. Mamund. ? families. I know nothing of this tribe but I expect it is really a sub-tribe of the Hamawand No. II, section A.

7. Girdi. 6,000 families. A powerful tribe of shepherds, agriculturists and warriors, occasionally robbers. Dress in Persian fashion, very wealthy and good horsemen. They employ the Khoshnao No. 21, section $A$, to do agricultural work for them. They proceed to the Wazna district in summer to pasture their flocks. One section of this tribe dwelling at Ushkafsakka is well disposed to strangers, another, living about four hours west of Ain Kawa, are noted highwaymen. Baban Kurds.

A. Girdi. 1,200 families. These Girdi migrated from the vicinity of Girdmamik about sixty years ago; they have abandoned the use of tents in the summer and are now not to be distinguished from the surrounding mountaineers. They are industrious and wealthy. They still correspond with the mother tribe and send presents to the chief at Ushkafsakka each spring. Baban Kurds.

8. Khalkani. 700 families. Semi-nomadic, but unwarlike. Baban Kurds.

9. Surchi. 3,000 families. 1,000 of the households are complete nomads. The Surchi have no peculiarities. Baban Kurds. A small tribe of Mamakanli, see section D. Nos. 8G and $9 \mathrm{~A}$ are attached to the Surchi, evidently they migrated southward at some time, and have become absorbed; see section A, No. 26.

10. Bejwan. 800 families. Speak a mixed language, apparently half Arabic, half Kurd, said by neighbours to be of Turkish origin and to be followers of Hajji Bektash.

11. Hamavand. 1,200 families. The most valiant, courageous, and intelligent of the Baban Kurd tribes. Splendid horsemen, crack shots, capable smiths, bold robbers, good agriculturists; such as enter the government service prove capable officials. In 1878, 600 Hamawand horsemen armed only with lances penetrated far into the Caucasus, and brought back immense spoils. The Turkish government has of late years done much to suppress this tribe's power, but the men are still famous for their prowess and intelligence, and the women for their beauty. The Hamawand intermarry freely with the Arabs, and reckon themselves of Arabian origin. Most of the Hamawand speak Arabic, their language is, however, Kurdish. Dress, partly Arab, partly Persian. Formerly they were noted lancers, however they now only carry a modern rifle and dagger.

12. Jaff. 10,000 families. A great semi-nomadic tribe, as famous as the Hamawand; Saladin was supposed to have been of this tribe; they 
inhabit both sides of the frontier. The Jaff leaders are noted for not betraying one another as do other Kurdish chiefs, hence their numbers and independence. They are supposed to dislike Europeans. Baban Kurds.

13. Guran. ? families. Baban Kurds.

14. Nuredi. ? families. Baban Kurds.

15. Piran. 900 families. Similar in customs to No. 3, section A; said to be a sub-tribe of the Hartushi, No. 76, section A. However, as I am not certain on this point, I have marked them as a separate tribe.

16. Alan. ? families. This name recurs in a sub-tribe of the Hartushi, (see No. 76E, section A) but I could find no connection. We see a tribe in section C, No. 15M, called Alian. Baban Kurds.

17. Baki Khassa. ? families. Baban Kurds.

18. Kialoner. ? families. Baban Kurds.

19. Ghowruk. ? families. Baban Kurds.

20. Malkari. ? families. Baban Kurds.

21. Khoshnao. 2,000 families. Completely sedentary. Work for Girdi and Shaykh Bezeini, Nos. 7 and 3, and occasionally look after crops of latter tribes during season of absence. Reputed to be poor fighters. Following account of origin was given me by chief Agha of the tribe:- "Ambesbudast was the son of Saranduz, and Saranduz was the Wazir of Sultan Selim. The son of Imam Hussein gave the forefathers of Ambesbudast a seal-ring and lordship over all the lands between Kermanshah and Mossul. Ambesbudast was the forefather of the Khosnao. The two saints of the tribe are Hanifa and Mazdak."

22. Bilbas. 400 families. Frontier tribe. Baban Kurds. Semi-nomadic, spend the summer at Wazna.

23. Acu. 500 families. Semi-nomadic, some live in the town of Rania, great warriors and good horsemen. Spend summer at Wazna. Baban Kurds.

24. Mamash. 2,000 families. Complete nomads. Baban Kurds, spend summer at Wazna.

25. Mengor. 2,000 families. A warlike tribe, semi-nomadic, spend summer at Wazna.

26. Mamakan. ? families. This tribe now counts as a sub-tribe of the Surchi, No. 9, section A; the name Mamakan, or variations of it, reappears in section C, No. 15E Del Mamikan, and in section D, No. 8G Mamagan, a sub-tribe of the No. 8 Jibranli, and No. 9A Mamakanli, a sub-tribe of No. 9 Sipikanli. Armenian priests and century

1 Mazdak, it will be remembered, was a founder of a religion in Persia during the sixth 
the tribesmen of No. $9 \mathrm{~A}$ state that the Mamakanli were Armenians who became Moslems. Probably they were a Christian tribe of nomads and have been completely scattered. The Mamakan, Mamagan, and the Del Mamakan have no tradition that I know of.

27. Baliki. ? families. A frontier tribe of which I know nothing more than that it exists, however it may be in some way connected with the Bellikan, No. 81, section $\mathrm{D}$, and with No. 15, section $\mathrm{E}$, Bellikanli. However, as the Bellikan, No. 81, are Zazas, it seems to me improbable.

28. Pirastini. 1,100 families. Baban Kurds. Village dwellers, similar to the Khosnao, No. 21, section A.

29. Zemzan. ? families.

30. Badeli. ? families. This is the name of a small sedentary tribe of Sunni Kurds living at Rowanduz; they acknowledge no connection with the Badeli, No. 1D, section E.

31. Shirwan. 1,800 families. Sedentary, their name is taken from the locality in which they live, industrious, hospitable, but warlike.

32. Herki. 3,000 families. A great nomadic tribe, much scattered, some are to be found near Erzerum, others near Van, and great numbers near Mossul. The Herki are a very dark-skinned people; their neighbours say they are not Kurds at all but some savage race. The Herki women are very bold and manly. The Herki sleep out in autumn without any tents. Taken as a whole they are a low, dirty tribe, owning large flocks of sheep, and dealing in inferior pack horses; it is impossible to mark them down with any accuracy, as they seem to have no fixed beats. They generally camp in small numbers and move about in little detachments. Their divisions are as follows:-

Mendan. We see the name again as a sub-tribe of the Milli in North Mesopotamia, see section C, No. 1G.

Zerhati. Sub-tribe of Herki, roves about in the vicinity of Van.

Zeydan. Sub-tribe of Herki. This name appears again as a sub-tribe of the great Pinianishli, No. 73, section $A$, and once again as a sub-tribe of Motikan, section B, No. 20E.

Haji. 200 families. Sub-tribe of Herki. This is the sedentary section of the Herki, and lives in the centre of the place marked with the number 32 .

33. Baradost. 1,500 families. Tribe taking its name from Baradost river.

A. Baradost. 650 families. Tribe taking its name from Bàradost river.

34. Berzan. 750 families. Taking tribal name from district of Berzan; this tribe is famous for its fighting qualities and a certain holy family known as that of the Shaykhs of Berzan. 
35. Nirva. 800 families. Sedentary.

36. Reikan. 800 families. Sedentary.

37. Zebar. 1,000 families. This is a district containing about 30 villages inhabited almost entirely by sedentary Kurds who are called Zebar Kurds. They are careful farmers, good vine growers, good builders, hospitable to strangers, but incredibly quarrelsome among themselves. Their chiefs build small castles in which they are generally being besieged unless they are besieging some one else. These Kurds are usually plucky fighters on their own ground. They have a chronic feud with the Shaykhs of Berzan, see No. 34, section A.

38. Ashaghi. I can give no particulars of this tribe.

39. Hasseina. ? families. A small broken tribe of nomads and villagers near Mossul.

40. Misuri. 120 families. A poor sedentary tribe.

41. Doshki. 500 families. At Dehok. This section has a bad name for thieving and brigandage. Kermanji, evidently an offshoot of No. 41A, section A.

A. Doshki. 2,000 families. Industrious agriculturists at Geaver (Giaver).

42. Jellali. 4,000 families. Both sedentary and nomadic near Amadia.

We find the name reappear in section $\mathrm{B}$, No. 14. The latter is evidently a migration from Amadia. However, whether this Jellali is the mother tribe of the Jellikanli, No. 12, section E, is by no means certain.

43. Dere. 800 families.

44. Berwari. 600 families. Sedentary.

45. Kohan. 70 families. Nomads, probably a sub-tribe, but of which I know not.

46. Shaykhan. Yezidis or devil worshippers. ? families. Semi-nomadic. This tribe dwells near Shaykh Adi, the religious centre of the Yezidis and the dwelling place of the religious head of the sect. There is also a temporal chief who used to live there, but I understand that he now keeps his whereabouts a secret. The tribe takes its name from Shaykh Adi. There is nothing to show that it has any connection, other than religious, with the Yezidis of the Sinjar. See section C, No. 16.

47. Reshkan. ? families. There are said to be some Yezidis in this tribe.

48. Haweri. Yezidis or devil worshippers. 300 families. These live near Zakho. I suspect some connection with the Haverka, section C, No. 151.

49. Spirti. 70 families. Nomads. The name was given me while passing their tents. I had not, however, time to investigate. 
50. Miran. 1,000 families. Low tribe of shepherds migrating from Jeziret ibn Omar to Lake Van in spring and returning in autumn. This tribe has an atrocious reputation for all kinds of villainy. Curiously enough they are usually very friendly to Christians and Europeans, but treat Moslems in a scandalous fashion. They move up to within about 15 miles of Lake Van annually, passing Shernakh on their way. They have a chronic feud with the Goyan tribe, section A, No. 53A.

51. Hasseina. 500 families. I cannot connect this with Hasseina, No. 39, section A.

52. Sindi. Total number of families 1,500. A mixed tribe of Moslems and Nestorians, latter in a'minority. Sedentary. Two sub-tribesSlope, 600 families, and Guli, 30 families.

53. Goyan. 1,400 families. A large and powerful tribe of sedentary and semi-nomadic Kurds. They have, I expect, several sub-divisions, but I have been unable to obtain their names. This branch contains a certain number of Zazas, for particulars of whom see section B. The Goyan are noted for independence and valour.- They slew Mustapha Pasha, the great chief of the Miran, in a pitched battle in 1899 .

A. Shernakhli. 600 families. Name given to a sedentary section of the Goyan living at Shernakh.

54. Dakhori. ? families. A few sedentary Kurds in the vicinity of Shernakh, probably a section of the Goyan.

55. Shiriki. 200 families. Wealthy sedentary tribe. Name suggests connection with the Zirikanli, No. 10, section D.

56. Balian. 70 families. Semi-nomadic, poor and scattered. Similar to the Herki, No. 32, section A.

57. Eiru. 100 families.

58. Atmanikan. 5,000 families. Very wealthy nomads. May be often seen in the Bitlis pass and near Bohtan, where their headquarters are. They dress like the Herki, No. 32, section A, but have not the bad reputation of the latter. They have hardly any horses. In summer they migrate up to the Mush plain.

59. Silukan. 900 families. Cultivators and nomads. Similar to No. 58, section A. Also migrate in summer to the Mush plain.

60. Kichian. 150 families. Nomads.

61. Duderi. 400 families. Nomads in summer on the south shore of Lake Van.

62. Alikanli. 150 families. Nomads. Very insignificant. Probably a sub-tribe, but could not discover whose.

63. Halaji. 900 families. Mixed sedentary Kurds, Turks, and Armenians. dwelling on the southern shores of Lake Van. 
64. Tiyan. 300 families. This tribe has a bad name. It is said by some to be an isolated fragment of the great Arab tribe of Tai, but I do not know if there are any grounds for this belief.

65. Hawatan. 300 families. Sedentary in the Bohtan district.

66. Keka. ? families. Near Julamerik.

67. Bellicar. 180 families. A small tribe of semi-nomadic Kurds; no connection with Belliki or Bellikanli. They state that they were converted from heathenism by Khalid Ibn Walid.

68. Khani. 180 families. Sedentary near Khoshab.

69. Takuli. 450 families. Perhaps a sub-tribe of the Zilanli; the Takuli think they came from Erzerum about 100 years ago. They are now sedentary, very poor physique, and appear to be of the same low race as the Sipikanli north of Lake Van mentioned in the introduction to section D.

70. ? families. Owing to an accident the name of a tribe has here been lost. I leave the number blank in hopes of some day re-discovering the right name.

71. Shekak. Total number of families 6,000. A notable tribe; they are called Revand by the local Armenians. They only spend three months in tents, and therefore may be called sedentary. The following sub-tribes are, I think, only an ancient political confederation, and not attached by ties of blood.

A. Shekifti. 1,200 families. Completely sedentary.

B. Mukeri. 1,200 families. Completely sedentary;' said to have migrated from Persia fifty years ago; split in two portions, one at Nourdous and one at Khoshab.

C. Sheveli. ? families. This tribe crops up again near Iskilip ; I presume a forcible migration in Selim's time.

D. Butan. ? families.

E. Sheveli. ? families.

F. Shekak. 1,000 families. A southern branch of the Shekak; complete nomads.

72. Zerzan. 100 families.

73. Pinianishli. 1,200 families. A large tribe and head of a confederation of which the following are the chief branches. It is impossible to locate them more precisely than by saying they inhabit the country in the vicinity of the No. 73, section A. The following are the names of the affiliated tribes.

Zeydan. There are some Zeydan in Modeki, No. 20E, section B, and as we have seen a sub-tribe of the Herki, No $32 \mathrm{C}$, section $\mathrm{A}$.

Bärkoshan. ? families.

Kinarberosh. ?

Suratawan. ? 
Billijan. ?

Jelli. ? families. I suggest the mother tribe of No. 12, section E.

Gewiji. ? families. I suggest the mother tribe of No. 12, section E.

Shevilan. Obviously a fragment of No. 71C and 71E, section A.

Musanan. For remarks see section B, No. 12.

A. Little Pinianishli. 500 families. Apparently an offshoot of No. 73. There is supposed to be something disgraceful about this tribe, what I do not know. 13 of its families are Yezidis, others Christians.

74. Givern. ? families. This is the name of a small tribe in the district of Giaver. Local authorities state that the name merely indicates Giaver-an, i.e., Giaver people, in which case it may have no connection with No. 8, section C, and No. 31L, section B.

75. Shemsiki. 900 families. An interesting tribe, once nomadic, now sedentary. The chiefs consider themselves of Arab stock and look on the common tribesmen as of low race. The tribesmen are very ugly as a rule, the chiefs refined and handsome.

76. Hartushi. This is a very important Kurdish tribe, and I suggest that investigation may some day show that it is the connecting link between the Kurds of Irak and the Kurds of Armenia. The nomadic branches of this tribe have a very bad reputation. Although richer than the Herki, No. 32, section A, they resemble them in mode of life and general appearance. The following are the subtribes.

A. Ezdinan. ? families. Said to be Yezidis. There is no mistake about the name.

B. Merzigi. 900 families. Sedentary near Bashkala.

C. Mamresh. 200 families. Yezidi religion but belong to Hartushi tribe.

D. Mamed. 200 families. I believe this sub-tribe of the Hartushi to be sedentary.

E. Alan. ? families.

F. Beroz. 60 families. Famous as cultivators of tobacco.

G. Jiriki. ? families.

H. Shidan. ? families.

J. Mamkhor. 400 families. Very warlike nomads.

K. Khawistan. ? families.

L. Sharafan. 3,000 families. The largest branch of the Hartushi nomads; descend south of Akra in spring.

M. Mamadan. 200 families. I think sedentary; some occasionally descend to the Beykhey Dagh, near Zakho.

N. Gavdan. 300 families. Nomads, very bad reputation as thieves, unhospitable and savage. Wealthy horse breeders. Camp in spring near Zakho. 
O. Zedek. Nomads.

P. Zefki. 150 families. Nomads, shepherds.

Q. Hafjan. 500 families. Nomads.

\section{SECTION B.}

The tribes inhabiting this zone are completely cut off from the others mentioned in the catalogue, and have little or nothing in common with them. The barriers which divide this region from the zones A, C, D and E, may be enumerated as follows.

Firstly, the great Bitlis Gorge, which can only be approached from either extremity and forms a kind of natural dyke between zone B and A. Secondly, the Tigris which is usually unfordable and practically interrupts all communication with C. Thirdly, the huge spurs of the Eastern Taurus range which act as a protecting wall against D. Fourthly, the upper Euphrates which separates the Dersim Mountains from the overlapping portions of zone $\mathrm{E}$.

From the point of view of a casual observer, I should be inclined to group the Kurdish tribes in this zone into five classes-

Class I. Would include numbers 1 to 10,27 and 29.

Class II. No. 20 and its appendant letters.

Class III. Nos. 12 to 19.

Class IV. No. 23.

Class V. No. 31 and its appendant letters.

As regards Class I, they appear to be semi-nomadic and sedentary tribes who have at some period migrated via the Bitlis Pass into the undulating arable pasture land between Diabekir and the Bitlis Su. These people may quite possibly be a part of that multitude of tribes who lived in a state of vassalage to the ancient Kings of Armenia; the names Bekran, No. 6, and Musik, No. 1, both well known in the old histories, give colour to this idea. At any rate these tribes of the southern plains own no connection with any of the tribes mentioned in the other classes.

As to the habits and dress of this class, I can give very few details, as on each occasion that I passed through their country, I was unable to make any study of them with the exception of the Tirikan, No. 9. The men appear to be tall and well built, fairly industrious, but not very hospitable.

Classes II, III, IV and V, are dealt with in the catalogue as classes en bloc and need no further comment.

1. Musik. ? families. This tribe has been mentioned by previous travellers, but I could obtain no account of it. I do not omit it because the Chaldean Historian Toma of Merdis makes mention of the name. There is, however, a village in Motikan called Mosik. None of the Motikan Kurds, however, make use of the name as a tribal designation. 
2. Penjinan. 500 families. A tribe noted for its fighting qualities. There are said to be some Yezidi families among them.

3. Keskoli. ? families. I am doubtful as to this tribes existence, it is probably a local name for a division of the Penjinan.

4. Pouran. 200 families. Semi-nomads, pastoral and agriculturists.

5. Shaykhdodanli. 200 families. I do not know if this tribe is sedentary or nomadic. There are a great number of non-tribal Kurds in this neighbourhood. A further difficulty lies in the fact that the Kurds of this region are averse to making known their tribal names or customs; resemblance of the name to the Duderi and Dudikanli should be noted.

6. Bekran. 500 families. Nomads; winter near Diabekir, and summer near Sairt; tradition states that they are the descendants of the Bagratians. The Armenian clergy generally speak with some certainty on this point. We see the name Bekiran, No. $16 \mathrm{H}$, section C, among the Yezidis of the Sinjar. The Yezidis of the Sinjar believe that they came from a country north of the Tigris.

7. Reshkotanli. 500 families. Nomads; the Rushdunians are often mentioned in the historv of Chamich, the Armenian priest; there is a peculiar resemblance in the name.

8. Besheri. ? families. A sedentary' tribe between Sairt, Meyfarkin and Diabekir.

9. Tirikan. 650 families. A sedentary tribe between the Euphrates and Haini ; fond of bright coloured clothes ; wealthy and intelligent; kindly disposed to the few Armenians who live among them. The local Armenians state that they are of common origin and that they (the Armenians) are not of Armenian race; this idea is naturally discouraged by the Armenian clergy and laity of Diabekir, but I have it on the authority of a priest and Christian headman of the district.

10. Kuzlichan. ? families. This is a small tribe located as on map; the name is that of a district in the Dersim Mountains, about 80 miles north. I think we may infer a southerly migration from that region.

$\left.\begin{array}{lrr}\text { 11. Zekeri } & \text { ? families. } \\ \text { 12. Musi. } & ? & " \\ \text { 13. Sarmi. } & 400 & " \\ \text { 14. Sellali. } & 100 & " \\ \text { 15. Khazali. } & 50 & " \\ \text { 16. Bederi. } & ? & " \\ \text { 17. Malashigo. } & ? & " \\ \text { 18. Bosikan. } & 180 & " \\ \text { 19. Kurian. } & 180 & "\end{array}\right\}$ See note, next paragraph.

Note,-The Bosikan and Kurian, Nos. 18 and 19, and the sub-tribe of 
the Bosikan, No. 15, inhabit the district between Mush and Kabeljôus. Their tradition is that they used to worship a sword thrust in the ground and the moon and stars, and that they lived under the government of a Christian King named Tavit, who dwelt in the castle of Boso. Presently there came a certain Shaykh Nasredin, from the Khalif at Baghdad, whoslew King Tavit and enlightened the people in the truths of Islam. The Emirs of Nasredin were Zakharia, Saru and Musa, and these brought with them their henchmen who formed the tribes of Zekeri, No. 11, Musi, No. 12, Sarmi, No. 13 ; after this settlement other tribes, namely, Malashigo, No. 17, Bederi, No. 16, and Jellali, No. 14, followed in the wake of the first and helped to drive the Bosikan and Kurian into the northern mountains. All these tribes have Armenians attached, and those with the Bosikan and Kurian are said to be the descendants of followers of King Tavit. None of the Armenians in this district bear any resemblance to those of the Mush plain or the villagers near Van, nor are they to be distinguished from the Bosikan and Kurian Kurds in dress or appearance. The Malashigo and tribes Nos. 11, 12, 13, 14, 16 call themselves Arabs, and besides talking Kermanji and Armenian, also talk among themselves a peculiar bastard Arabic which is just comprehensible, but almost as different from ordinary Arabic as is Italian from French. It is far more difficult to understand than the Arabic spoken at Sairt. At Tillù, a large village in the vicinity of Sairt, resides at present a certain Shaykh Nasredin, who is supposed to be the lineal descendant of the Shaykh Nasredin, previously mentioned. I met one of his nephews who told me that the family had a document giving them Tillu and certain lands; this paper was signed by Sultan Selim the conqueror of Persia. The family consider themselves to be of Abbasid stock and although few of them ever leave Kurdistan they make it a point to talk good Arabic among themselves. Shaykh Nasredin's nephew, who appeared a very well read man, told me he thought that the tribes Nos. 11, 12, 13, 14, 16, 17 were not really of Arabian origin but that they had accepted Islam and changed their tribal names for those of their conquerors whose language they adopted and then corrupted. ${ }^{1}$

20. Modeki (Motikan). This is the name of a peculiar and inaccessible mountain region north of Bitlis, and incidentally the appellation of

1 We have already seen the name Jellali in section A, No. 42, and the Musanan, No. 73, section A, perhaps the tribes Musi and Jellali, Nos. 12 and 14, section B, are descendants of some of the former who may have assisted Shaykh Nasredin. 
all Kurds who dwell within it. I endeavoured to effect an entrance but was unable to do so; anyone wishing to explore this district must do so on foot; the tribes inhabiting it are apparently mostly Zazas ; they are extremely wild and shy, and difficult to talk to. Other Kurds who had been into the Motikan district supplied me with the following particulars :-
A. Keyburan. Zaza Kurds.
B. Bubanli.
C. Kusan.
" ,
D. Rutchaba.
$" \quad$,
E. Zeidan. Kermanji Kurds.
F. Erikli.
(Sometimes called Khiarta).
G. Pir Musi.

"

By all accounts the Bubanli are the most ancient tribe in Modeki, the Zeydan, as we have seen in No. 32, section A, and No. 73, section A, are split as sub-tribes elsewhere. If the story that the Kermanjis of Motikan are slaves to the Zazas be true, there would be some ground for supposing that the former entered as refugees, particularly as the extremely difficult nature of the ground forbids the idea of its being conquered by anything but a regular army. Apparently the Zazas of Motikan are neither Moslems nor Christians. I would suggest that a thorough exploration of this district would prove very interesting, and might throw a wonderful light on the history of Armenia, if a good collection of folk songs and legends could be made.

21. Pinjari. 450 families. Sasun district speak Kermanji.

22. Slivan. ? families. Probably Zazas.

23. Non-Tribal Zazas. 1,000 families. In the locality where this number appears there are a quantity of non-tribal Zazas. Their state is almost anarchical, and they seem, although not naturally cruel or vicious, to have hardly any regard for human life; they frankly say they are as beasts of the field, and have hardly any religion. As an example of how unsophisticated these people are, I might cite the fact that such as I have met who have served in the Army have often become devout Moslems and look with shame on their previous state. They appear to have no idea of tribal organization. They speak the Zaza language and seem very poor farmers.

The Zazas are small, impish people with shrill voices, and are extremely shy before strangers. I should imagine that they are the remains of a primitive mountain race, similar to the Bihls.

The only instance I have encountered of Zazas living on the plains or in the country is at Suverek, where a few live with the Karagetch. 
24. Kedak. 600 families. Zazas due south of Peru on the Veshin Dagh.

25. Ashmishart. 500 families. Zazas. Shia sect.

26. Kulbin. ? families. Zazas.

27. Gurus. ? families. Beyond the name I could obtain no particulars concerning this tribe. Ibrahim Pasha, ${ }^{1}$ however, knows the name.

28. Sinan. ? families. Zazas.

29. Elia. ? families. Nomads ; impossible to ascertain whether Zazas or Kermanji Kurds.

30. Behirmaz. 500 families. Zazas. Shia sect.

31. Dersimli. General appellation of Kurds living in the Dersim. With the exception of No. 31C, section B, Shawak, all the Dersim tribes are apparently Pagans, who call themselves Shias, their religion, as far as I could ascertain, being a mixture of magic and nature worship, which again develops into Pantheism. A man of this region said to me, "I do not worship God, for a part cannot worship the whole." However, they are Shia Moslems in outward form, swearing by Ali, and call him the greatest of the prophets, this, I think, chiefly to annoy the Sunnis. The Dersimli are doubtless robbers and cutthroats, but I doubt their courage, since a very little show of authority suffices to keep them in their fastnesses, whither it is difficult to follow them. All round the foot of the Dersim there are tribes who live in a kind of feudal vassalage to Beys who talk Turkish and veil their women; at first I imagined these Beys were the descendants of Turkish Military Fiefs, of whom one is always hearing and never meeting; as on former occasions these "Turkish" Beys turned out to be the descendants of indigenous chiefs, who have settled down and adopted Turkish customs. The Dersimli are small, wiry men with sharp features; they are intelligent and have a keenly developed artistic sense for colour and dress. There are indeed on the slopes of the Dersim some Turks, but they are Ak Koyunlu, of Usun Hassan, and live in a kind of commune of their own ; for history of latter see Deguigne's Histoire des Huns. As far as I could ascertain, the Dersimli have a special dialect of their own but it is closely allied to Zaza.. Most of the Dersim tribes are regular migrants from south to north in late spring; their villages are left quite empty without caretakers.

A. Milan. This is the original mother tribe of the great Milli confederation in North Mesopotamia, with whom they still keep up communication. For particulars of the legend and importance attached to the name Milli or Milan, see No. 1, section C.

B. Kechel. 1,000 families. Near Palu.

No. 1, section C. 
C. Shawak. ? families. Sedentary ; lately converted to orthodox Sunnism.

D. Ferhad Ushaghi. ? families. In the vicinity. of Surpignan. This is the only Kurdish tribal name beginning with $\mathrm{F}$.

E. Bakhtiarli. ? families. Perhaps 30 villages near Chemishgezek; seminomadic, or at least migratory, having two villages, one on the high land and one in the valley.

F. Karabanli. ? families. At Asunik.

G. Mirzanli. ? families. Exact location in Dersim unknown.

H. Abbasanli. ? families. Make splendid carpets of great intricacy of design and fineness in weaving.

I. Balashaghi. 2,000 families. Sedentary.

J. Latchin Ushaghi. ? families. At Amuga.

K. Kuzlichan. ? families. This is certainly not the name of a tribe, but of a Dersim district containing several tribes; however, the name crops up as that of a tribe north of Diabekir, I presume a migration of some families from the Dersim.

L. Givran. ? families. Reported to be in Dersim, but I am doubtful.

\section{SeCtion C.}

This zone is in reality the ancient province of the Northern Jazirah of the Empire of the Khalifs of Baghdad; the Kurds inhabiting it may be roughly classed as follows :-

Class I, No. 1 and appendant letters. This class may be divided into two subsections-

(1) No. 1 to No. 1 Dx.

(2) No. 1 Ex to No. $1 \mathrm{Rx}$.

Class II, No. 15 and appendant letters.

Class III, No. 16 and appendant letters.

Class IV, the remaining numbers with the exception of 18 and 19.

With regard to Class I, subsection 1, they are evidently partly formed of a great migration from the Dersim district in the reign of Sultan Selim, but owing to intermarriage for many generations with the Arab, Aramean and Kurdish peoples of the district, and by absorbing many of the local tribes, they have lost their original characteristics. They are poor cultivators, but good herdsmen and carpet weavers.

Their mode of life is simple, January, February, March and April they spend in the lower slopes of the Karaja Dagh; April and May on the plains of Mesopotamia; June, July, August and September sees them move up towards Diabekir ; in October, November and December they move once more southwards.

Subsection No. 2. These tribes admit themselves of the same race and origin as subsection No. 1, but are cut off from it by the Euphrates river; they are 
all Shias or Pagans of the Dersimli type. At certain seasons priests from the Dersim district visit them and hold religious services.

Their dress is similar to that of the.Turkish speaking people of Anatolia; however, their women veil before Moslems and Christians. The men are not very remarkable for any particular characteristic.

Class II.-It is very difficult to state with any preciseness whether the tribes included in this class can be termed Kurds proper or no. I presume that they represent scattered fragments of the old Aramean population, mixed with Imperial colonists of Roman times, Kurds, Persians, Turks and Mongols.

Some tribes are wholly Moslem, others wholly Christian (Jacobite sect), others Devil worshippers, others contain adherents of all three religions. Taken as a whole they are industrious and capable people, good stone-masons, and admirable vinegrowers, but withal fierce, bloodthirsty, vindictive, revengeful, and treacherous. Peculiar religious movements are not uncommon amongst them, and the adoption of Evangelical Protestantism by a certain number has been productive of unexpected developments.

Class III.-The great Yezidi or devil worshipping community and tribal confederation of the Sinjar is entirely Kurdish. In physique the Yezidis of the Sinjar resemble the Dersimli Kurds, being small-boned, wiry, lean and hungrylooking men, with pinched features, small hooked noses, pointed chins, broad shallow lower jaws, high cheek bones, narrow close set black eyes, and thin lips. They twist their hair in six or seven small braided plaits which hang down on either side of their faces.

The dress of the Sinjar tribes is unlike that of any other people, and I should imagine of remote antiquity. It consists of a pointed brown felt cap, a white shirt of cotton cut square at the neck and with no opening in front, a cloak of gazelle skin or light brown leather, raw hide sandals, and leather belt.

By their own tradition they migrated to the Sinjar after Timur's invasion. However, they admit that the Yezidi faith existed in the Sinjar Mountain long before that date.

Class IV.-These Kurds of North Mesopotamia are the off-scourings and riff-raff of all Kurdistan, rogues, thieves, vagabonds and bullies almost to a man; they seem to have no single redeeming virtue, being idle, cowardly and cruel. They have little pride of race and seemingly intermarry and mix with gypsies and other low nomad tribes. From this class, however, must be excepted No. 18, No. 19, and No. 10, who have evidently migrated at some period from the plains north of Lake Van.

Note.-East of Urfa there is a large settlement of gypsies, who will pretend they are Kurdish tribesmen; the traveller should be on his guard against the information they will give him. The word "Nowar," or the question, "Do you come from Howek?" will invariably silence them, or make them admit their true origin.

1. Milli. 30 families. This name has a curious and peculiar mystery attached to it, which innumerable cross-examinations on my part of 
every kind of Kurd has failed to elucidate to my own satisfaction. Some people merely say that the Milli were a powerful tribe who were broken up by the Turks in the 18th century. The facts at present stand as follows:- Ibrahim Pasha is chief of the Milli, and although his own tents do not amount to more than 30 , he has complete jurisdiction over more than 2,000. Secondly, he is spoken of with great respect and reverence by the Kizilbash of Malatia, not because he is wealthy but because he is the head of the Milli ; thirdly, he is the only stranger who can travel through the Dersim without an escort; fourthly, the Shemsiki, No. 75, section A, look on him as their nominal head; fifthly, isolated villages in Anatolia and the Erzinjian district speak of him as their patriarchal chief. Now this is all the more peculiar since in the Kurds enumerated there are Shias, Pagans, Pantheists, Zazas and orthodox Moslems, of which latter faith he is; his influence is therefore neither political nor religious, and yet influence he has, for Kurds will come from miles around to ask his opinion on family quarrels and generally take his verdict as final.

Again there are certain tribes which although allied to him in war have no regard for his Patriarchal position. Ibrahim's own explanation is as follows:- "Years and years ago the Kurds were divided into two branches, the Milan and Zilan; there were 1,200 tribes of the Milan, but God was displeased with them and they were scattered in all directions, some vanished, others remained; such as remained respect me as the head of the Milan."

Now the tradition with Ibrahim is that all this happened long before the days of Mohammed, thus some Milan are Christians, others Yezidis; the Milan tradition is that they are children of Shem and came from Arabia, but that the Zilan are from the East. Now this vague legend is found almost in its entirety among the Kurds of the Dersim, save that there we have the following variation :-

The Milan came from Arabia and settled in the Dersim; however, when Sultan Selim conquered West Kurdistan, his Vizier saw that the Kurds wandered up and down the Dersim slopes, and that the land was crowded with nomads, the Vizier ordered such as wished to cultivate, to build houses, and such as wished to remain in tents, to go south; some built houses, learned Turkish and veiled their women, others fled to the Dersim fastnesses, and others went south, among the latter the chief family of whom Ibrahim Pasha is now the head.

Among other stories of the Milan is the one that the Zilan are a base and ignoble race; curiously enough, whereever one meets a tribe admittedly of Zilan origin (they are in section D, Nos. 6, 9, 
$9 \mathrm{~A}$, and 17) you find rough and barbarous people with a peculiarly hideous cast of countenance. The legend to me is extremely interesting, but the way in which Milan Kurds would suddenly grow vague or change the subject while relating fragments of it was more than maddening. The reader would be surprised if he knew the months of toil I endured in collecting the above small paragraph.

All avowed Milan tribes are starred.

*A. Danan. 250 families. Nomads.

*B. Seidan. 450 families. Nomads. We have seen a similar name in section A, Nos. 32 and 73, and section B, No. 20E, but on this occasion I suggest the name is derived from some leader, either a Sayad or a man called Said.

*C. Kiran. 550 families. Nomads. Ibrahim Pasha suggests that these are of the same tribe as the Yezidi tribes; of course these Kiran are orthodox Moslerns.

*D. Dudikanli. ? families. Nomads. With Ibrahim in N. Mesopotamia; there are five villages near Varto who speak Zaza, and there are said to be some in the Dersim, see section B.

(?)*E. Khalajan. 700 families. Nomads.

(?)* Kelish. ? families. Nomads.

*G. Mendan. ? families. Nomads, a small sub-tribe of No. 1; whether these have moved from the Herki, No. 32, section A, to the Karaja Dagh or vice versa, is difficult to say.

*H. Kumnaresh. 350 families. Nomads.

*I. Sherkian. 80 families. Nomads.

*J. El Kawat. ? families. Nomads.

*K. Dashi. ? families. Nomads.

*L. Meshkenli. ? families. Nomads.

*M. Kalendelan. ? families. Nomads reported in the Dersim, section B.

*N. Haji Bairam. ? families. Nomads.

* O. Hassanekan. 260 families. Nomads. These have nothing to do with the Hassananli, who are avowedly Zilan.

*P. Khalajari. 700 families. Nomads.

*Q. Elia. ? families. Nomads.

*R. Isiadat. 85 families. Nomads.

*S. Terkan. 700 families. Nomads.

*T. Nasrian. 75 families. Nomads.

*U. Tchuvan. 210 families. Nomads.

*V. Sartan. 80 families. Nomads near Ras-ul-Ain.

*W. Usbakhan. 70 families. Nomads.

*X. Matmieh. 800 families. Nomads.

*Y. Chemikan. 250 families. Nomads.

*Z. Barguhan. 130 families. Nomads. 
*Ax. Hisulieh. 550 families. Nomads.

*Bx. Chiaresh. ? families. Nomads.

*Cx. Zirofkan. 2,000 families. Semi-nomads of the Karaja Dagh.

*Dx. Daghbashi. ? families. A large semi-nomadic tribe east of Suverek.

*Ex. Bujak. ? families. Nomads.

*Fx. Hoshian. ? families. Nomads.

(?)*Gx. Beski. 800 families. Apparently sedentary. A curious legend of this tribe is that they are of English or Frank origin and that their ancient name was Salargan. With reserve I suggest the name Lusignan, and as an explanation that some member of that house once had dealings with the tribe or took refuge in its tents.

*Hx. Haji Manli. 500 families. Nomads. No horses, travel small stages with donkeys.

*Ix. Kassiani. 500 families. Sedentary.

*Jx. Chakali. 1,000 families. Nomads.

*Kx. Merdis. 1,000 families. Sedentary, I think.

*Lx. Eutergetch. ? farnilies. Nomads.

*Mx. Janbeg. ? families. Sedentary; obviously a fragment of No. 18, section $\mathrm{F}$.

*Nx. Beyleyan Porga. 500 families. Sedentary.

* Ox. Derejan. 800 families. Nomads.

*Px. Kao. 5,000 families. Nomads and sedentary.

*Qx. Mulikan. 500 families. I do not know if nomad or sedentary.

*Rx. Derejan. ? families. Possibly a separate branch of No. 10x, section C or perhaps only the summer quarters of that tribe.

2. Karagetch. 1,700 families. This is the name of a low tribe of seminomads dwelling near Suverek; brutal, savage and indescribably filthy. This tribe has a bad name in every respect, and being on a high road gets a bad name for Kurds from many travellers. Curiously enough many of the Karagetch speak Zaza, but between Diabekir and the Tur Abdin there is a vast quantity of nameless non-tribal Kurds, who apparently are outcasts from their own clans; the worst of these "undesirables" seem to attach themselves to the Karagetch. ${ }^{1}$

1 Karagetch. This tribe was originally a nomad Turcoman clan of Western Anatolia and was settled by Sultan Selim on the slopes of the Karaja Dagh. The object of this transfer was to compensate Kurdistan for the loss of the Ziriki, Tirikan and other tribes which the Ottoman Government had forcibly settled in West Anatolia. The Karagetch, however, rapidly intermarried with local non-tribal Kurds of low origin, and being illiterate soon lost their language and became to all intents and purposes a Kurdish tribe. Further, owing to the fact that for some years after their re-settlement they were protected and favoured by the Ottoman Government, many families of local nomadic Kurds joined their encampment and so helped not only to increase their numbers but to complete the transformation of the Turcoman clan into a Kurdisb tribe. 
3. Non-tribal Zazas. For an account see No. 23, section B.

4. Chaikessen. ? families.

5. Barhan. ? families.

6. Hasseran. ? families.

7. Abu Tahir. ?families. These are said to be of Arab origin but talk Kermanji.

*8. Givran. ? families. Sub-tribe of No. 1, section C. (Accidentally left out of the letters.)

9. Eimerzan. ? families. 'This is a doubtful tribe.

10. Chichichieh (Kiki) (Kikie). 1,200 families. This is a large tribe of semi-nomadic Kurds, now inhabiting the slopes of the Karaja Dagh in winter (in villages) and descending in the Jagh-Jagh River in spring and early summer. Their chiefs state that they are the descendants of an Emir sent to rule the Diar Erabieh by the Abbasid Khalifs.' When the Khalifate grew weak this family remained and was taken by the Kikieh Kurds as a ruling family. The local Bedawin look on this family of chiefs as men of good blood. The chiefs have a notable contempt for their tribesmen, who they talk of as "Kurdish Dogs," and I believe will not marry their women. The chief Agha of the Kikieh, Abdur Rahman, is a well read man, and has done a good deal of work with a view to locating the ancient cities on the banks of the Khabur; he has read a certain amount of history, and states that the Kikieh were one of the last remnants of the sedentary population of the Jazirah, that they were driven north by the Shammar, and only come south with the object of showing their rights of settlement in event of further re-establishment of agriculture in the north Jazirah.

11. Dakhori. ? families. A small migration from Shernakh.

12. Bunesi. ? families. I think this tribe does not exist, but as travellers have reported it I give the name.

13. Mirsinan: ? families. No particulars obtainable.

14. Surkishli. 900 families. Sedentary. This tribe is said to speak the dialect of Baban Kurds; if so, perhaps, connected with Surchi, No. 9, section A.

15. Under this number I have grouped the Moslem, Yezidi and Christian tribes of the Tur Abdin.

A. Mizizakh. 390 families. Tur Abdin. Moslem. Kurds.

B. Saur. ? families. Tribe of the Tur Abdin; mixed Christians and Moslems; speak Arabic.

C. Mahalemi. 800 families. This tribe has a peculiar history. They state that 350 years ago they were Christians. During a famine of corn they asked the Patriarch permission to eat meat during Lent. The Patriarch refused, and they became Moslems. They speak a 
bastard Arabic, and the women wear red clothes and do not veil. Ibrahim Pasha says they are now a mixed race of Arabs and Kurds. Some families are still supposed to be Christians.

D. Haruna. 750 families. Sedentary Kurds; 90 of the families are Jacobite Christians.

E. Del Mamikan. ? families. A tribe of the Tur Abdin; speak bastard Arabic.

F. Domana. 180 families. Tribe of the Tur Abdin; Christians and Moslems.

G. Dorkan. 120 families. Tribe of the Tur Abdin mountain, composed of Yezidis and Moslems.

H. Moman. 600 families. Moslems, speak Kermanji; 90 families are Christians, also three of the tribal leaders.

I. Haverka. 1,800 families. Half Christian, half Moslem, speak Kermanji. I suspect some connection with the Haweri Yezidis, No. 48, section A.

J. Salahan. ? families.

K. Girgiri. 500 families. Tent-dwelling agriculturists; talk Kermanji, but said to be of Arabian origin.

L. Dasikan. 900 families. Yezidis, Moslems and Christians; speak Kermanji ; Tur Abdin.

M. Alian. 1,200 families. Christians, Moslems and Yezidis; language, I think, Kermanji.

N. Mizidagh. ? families. See No. 15A. I suspect these to be a small nomadic section of No. $15 \mathrm{~A}$, who live close at hand.

16. Yezidis of the Sinjar.

A. Bumteywit. ? families. A tribe of Arabs living in a state of serfdom to the Yezidis of the Sinjar.

B. Mirkan. ? families. Sedentary.

C. Samuga. ? families. Dwell in tents near the Sinjar; I suspect the name of this tribe is derived from the locality in which they live.

D. Beit-el-Khulta. ? families. Sedentary.

E. Hababa. ? families. Sedentary.

F. Kiran. ? families. Tent dwellers in Sinjar; there are some other Moslem Kiran which have been noted. See No. 1, section C.

G. Beled. ? families. Sedentary Yezidis dwelling near the town of Beled Sinjar, and go by this name.

H. Bekiran. ? families. Sedentary; perhaps a section of the Bekiran near Diabekir.

I. Mendikun. 300 families. A tribe of nomadic Yezidis between Tell Afar and Beled. A certain number of the Mendikan are Moslems, and do not intermarry with the Yezidis. I could not ascertain whether they were Arabs who had attached themselves to the 
Mendikan or not. At any rate on all matters of business they are on good terms with their devil-worshipping fellow tribesmen. I may note that Father Chamich's History of Armenia makes frequent mention of the Mandukanians.

17. Alush. 200 families. A tribe of outcasts and refugees under a Kurd chief; language Arabic.

18. Berazieh. 9,000 families. A branch of the Berizanli, No. $6 \mathrm{~A}$, section $\mathrm{D}$, who have migrated at an unknown period to Seruj in North Mesopotamia. This is a confederation of the following tribes :-

\begin{tabular}{|c|c|c|c|c|c|}
\hline Keytkan ... & $\ldots$ & $\ldots$ & $\ldots$ & $\ldots$ & $\begin{array}{l}\text { Families. } \\
700\end{array}$ \\
\hline Shaykhan... & $\ldots$ & $\ldots$ & $\ldots$ & $\ldots$ & 600 \\
\hline Okian & $\ldots$ & $\ldots$ & $\ldots$ & $\ldots$ & 700 \\
\hline Shadadan & $\ldots$ & $\ldots$ & $\ldots$ & $\ldots$ & 700 \\
\hline Alidinli ... & $\ldots$ & $\ldots$ & $\ldots$ & $\ldots$ & 700 \\
\hline Ma'afan ... & $\ldots$ & $\ldots$ & $\ldots$ & $\ldots$ & 700 \\
\hline Zerwan ... & $\ldots$ & $\ldots$ & $\ldots$ & $\ldots$ & 500 \\
\hline Pijan & $\ldots$ & $\ldots$ & $\ldots$ & $\ldots$ & 800 \\
\hline Karagetchan & $\ldots$ & $\ldots$ & $\ldots$ & $\ldots$ & 500 \\
\hline Dinan & $\ldots$ & $\ldots$ & $\ldots$ & $\ldots$ & 1,000 \\
\hline Mir & $\ldots$ & $\ldots$ & $\ldots$ & $\ldots$ & 1,000 \\
\hline Didan & $\ldots$ & $\ldots$ & $\ldots$ & $\ldots$ & 300 \\
\hline
\end{tabular}

The fact that the Karagetchan appear in this list does not prove that the rest of the confederation should date their settlement at Seruj from post-Selim times. Their tradition is that they hail from Lake Van, whence they came during a famine year. They are now partly "Arabised," and many wear Arab dress and have adopted Arab speech. They are partly complete nomads, partly completely sedentary, and partly semi-nomadic. They have rather a bad reputation for freebooting, but are industrious and intelligent.

\section{SECTION D.}

The tribes inhabiting this zone are extremely complicated in organization, and very difficult to order and catalogue. As far as I can see they seem to fall into three classes.

Class I.-Nos. 6, 6A, 8, 9 to $13,17,23,24$.

These tribes are of a distinct and distinguishable race of tall, heavily built men, of surpassing ugliness of face and peculiar uncouthness of behaviour. Many travellers have generalized from them and imagine all Kurds to resemble them.

They are seemingly true nomads by instinct, and lack capacity of any kind for either war or agriculture, they appear at once stupid and treacherous, disloyal, rapacious and quarrelsome. However, they must have some qualities which are not apparent, since they seem to have been the masters of the country which they inhabit long before the government of Constantinople had any 
power there. Their traditions state that they originally came from Diabekir, and were at one time either Armenian Christians or worshippers of fire. In many cases they have affiliated local tribes to themselves, notably the Jibranli, No. 8. But the affiliated tribesmen such as the Bellikan, No. 8I, are very easy to distinguish by physiognomy alone. A peculiar custom subsists among them as their women shave the hair of the scalp in a tonsure-like form. They are all orthodox Sunnis.

Class $I I$, in which I would include Nos. 8A, 8B, 8C, 8D, 8E, 8F, 8G, 8H, 8I, 9A, 18, 19. These tribes $I$ am inclined to look on as the original shepherd tribes of the region, who inhabited it before Class I entered the district; they are usually small, fine-featured, inoffensive people, with no very salient characteristics.

The Mamakanli are the most interesting in this division, for details see catalogue.

Class III.-I would suggest that Nos. 7, 16, and $16 \mathrm{~A}$ are bodies of exiles sent from their native places by Sultan Selim the conqueror of Erzerum.

Class IV.-The remainder of the tribes in this region of whom I can give no details.

1. Penjinan. ? families. Nomads. Summer quarters, a few villages in the vicinity; call themselves Penjinan, No. 2, section B.

2. Silukan. ? families.

3. Chukurli. ? families.

4. Azli. ? families.

5. Lolanli. 480 familiés. Shia section.

6. Hassananli. 3,300 families. A large tribe owning 110 villages in the districts of Hinis Melasgird and Warto. Some of the members of this tribe are semi-nomadic, but have been gradually abandoning their tents of late years.

6A. Berizanli. 900 families. This is a sub-tribe of the Hassananli; all are now sedentary; probably the mother tribe of No. 19, section C.

7. Isoli. ? families. Some near Lake Van, possibly a fragment of the Hisulieh, No. 1Ax, section C.

8. Jibranli. 2,000 families. This is a tribe and confederation of 8 tribes as follows:-

A. Mulkhel. ? families.

B. Arab Agha. ? families.

C. Torini. ? families.

D. Aliki. ? families.

E. Asdini. ? families.

F. Shaykhekan. ? fanilies.

G. Mamagan. ? families. Probably connected with the Mamakanli, see No. $9 \mathrm{~A}$, section D.

H. Shadelri. ? families. Shias. A break off from No. 1C, section E,

I. Bellikan, 6,000 families. Zaza speaking Kurds, Shias. 
The tradition of the Jibranli is as follows:-They lived in Arabistan (this to a Northern Kurd may mean Diabekir) three months in houses, nine months in tents each year. A certain Assad Pasha ordered them to go to Bingol, near Mush. The Jibranli are now rapidly becoming completely sedentary. It seems pretty clear to me that this tribe is composed of the Jibranli and fractions of others who have separated from their own clans. These, I expect, were the original inhabitants of the mountains before the arrival of the Jibranli, by whom even now they are roughly treated, and apparently live in a kind of vassalage to them. The Bellikan are somewhat more independent of the Jibranli and keep to themselves. The Jibranli women shave the top of their heads as do the men. The men wear the most extraordinary clothes, something after the fashion of East-end costermongers, pearl buttons, black velvet collar and cuffs, baggy trousers, sash, and, among the well-to-do, a collar and tie; on the head is worn an enormous white felt tarbush about 1 foot high bulging out like a busby; around this is turned a very small turban of silk. These are the only Kurds I have seen who dress in this way; I expect the costume, except for the tarbush, is a modern development. Another peculiarity of the Jibranli is that they wear carefully trimmed mutton-chop whiskers and long hair; the whole combination is more than fantastic. I might add the Jibranli in appearance resemble the Haideranli, being grotesquely ugly.

9. Sipikanli. 3,000 families. This is a base tribe dwelling north of Lake Van, they have the same rough manners as the Haideranli.

A. Mamakanli. ? families. Now count as a sub-tribe of the Sipikanli ; they have been stated by some to be the ancient Mamagonians of the Armenian histories.

10. Zirikanli. 6,000 families. A tribe similar in all respects to the Jibranli, No. 8, section D, save it is one block tribe, as far as I know, with no proper subdivisions. I could not ascertain whether they also reckoned themselves from Arabistan. They were nomadic, but have settled during the last 10 years.

11. Rashwan. 70 families. Nomads.

12. Bazikli. 70 families. Nomads.

13. Putikanli. ? families. Near Khighi Kermanji, sedentary.

14. Girdi. ? families. Evidently a migration from No. 7, section A.

15. Pisianli. 700 families. Kermanji. Sedentary.

16. Shaykh Bezeini. 450 families. Two or three sedentary villages at Erzerum, obviously a migration from No. 3, section A.

A. Shaykh Bezeini. ? families. Reported to be some near Tortwin, a migration from No. 3, section $A$.

17. Zilanli. ? families. 
18. Badeli. ? families. At Alashgerd. Shias.

19. Shaderli. ? families. A few semi-nomads at Alashgerd. Shias.

20. Bashmanli. ? families. Same as No. 56, section A? There are said to be many of this tribe in Persia, similar to, and connected with, No. 56, section A.

21. Hamdikan. ? families.

22. Manuranti. ? families.

23. Haideranli. 20,000 families. The largest Kurdish tribe in existence to be met with from Mush to Urumia. The whole tribe are a low rough race of people of no merit either as soldiers, agriculturists or shepherds.

24. Adamanli. 1,800 families. Semi-nomadic.

25. Yezidis. I was unable to discover the name of this tribe, who are devil-worshippers.

\section{SECTION E.}

This zone, which lies between the Kizil Irmak and the Euphrates, presents the traveller with a picture totally different to any other in Kurdistan. The Kurds have a different position, and no observer could imagine they belonged to the same race as those described in the preceding catalogues; however, the dialects correspond pretty closely, though a Kurd from section A would find great difficulty in making himself understood. The tribes fall fairly easily into four classes :-

Class I. Containing all Kurds included in No. 1 and its appendant letters.

Class II. No. 2 and its appendant letters.

Class III. No. 3 and other tribes in its vicinity whom I have been unable to catalogue.

Class IV. The remaining numbers.

With regard to Class I, the Kurds in this division are completely sedentary, build fine villages, are industrious and intelligent, peaceful, but extremely treacherous, and on occasion ruthless and cruel. Fair hair and blue eyes are not uncommon among them; the men are generally short but handsome, and very submissive in their demeanour. To each of these tribes are attached certain families of nomads, all extremely poor, dark skinned and repulsively ugly, who claim common origin with the village dwellers.

The whole of Class I are reputed Shias, but undoubtedly have a secret religion.

Class II stands by itself, and I must refer the student to the catalogue.

Class III, the Sinaminli, I have been inclined to connect with the Milan tribes Nos. $1 \mathrm{Hx}$ to $1 \mathrm{Rx}$, section $\mathrm{C}$.

However, I have come to the conclusion that this would be a mistake. Police and government officials count them all as Kizilbașh Kurds, but I am inclined to 
think the Sinaminli are really exiles from Azerbaijan. They are complete Shias, but certainly have no Pagan rites or secrets.

They are fine handsome people, good farmers, literate, and very artistic in the painting of the interior of their houses.

Class IV are, generally speaking, nomads from Diabekir or Lake Van, who have drifted down the Taurus slopes toward the Mediterranean.

They are now settling down as sedentary agriculturists, or hire themselves out as shepherds. The shepherds dwell in tents with stone walls in winter, tents in summer, and bowers in autumn, they are kind and hospitable; and have a good reputation.

1. Kureshli. 2,000 families. Speak Kermanji; Shias or Pantheists. These Kermanji speaking Kurds of the north are an utterly different race to any of the foregoing tribes; they are a handsome, quiet people, who detest orthodox Moslems, and are always very reserved and quiet in the presence of the latter; they seem to have no predatory or nomadic instincts at all, but behind their silent demeanour there is a strange, savage spirit, which I have noticed among no other Kurds. They are excellent farmers and much inclined to philosophic speculation, this latter point is curious since they are seemingly illiterate. Another point in which they differ from all other Kurds is their peculiarly quiet manners and lack of humour.

A. Balabranli (small). 60 families. Shias in name; dwell on the opposite bank of Euphrates; curiously enough these people talk the Kermanji dialect. Seemingly they are more akin to the Badeli, No. 1D and No. $1 \mathrm{C}$, section E, in appearance than to the Dersimli.

B. Balabranli (great). 500 families. A little south of Erzinjian, Zaza speaking, Shias in name, apparently Pantheists.

C. Shaderli. 3,000 families. Shias or Pantheists, a type similar to, but lower than, the Kureshli; live in underground houses; very poor agriculturists.

D. Badeli. 700 families. Kermanji Shias, semi-nomadic. There are said to be a few near Rowanduz.

2. Kochkiri. 10,000 families. This is a very peculiar tribe, or perhaps one might almost call them a separate nation. The men and women are of a peculiar type, being dark with finely-chiselled features, and resembling no other Kurdish race. Their language is seemingly a dialect of Kurdish, but hardly comprehensible to Zazas or Baba Kurds, or Diabekir Kermanjis. In religion I take them to be advanced Pantheists, who recognize nature as a female principal and God as a male. This opinion I give with every reservation as the result of interpreted conversations with well-to-do elders. The Kochkiri are miserable farmers, and dwell in semi-underground dwellings similar to those in the Mush plain and north of Lake Van. 
A fact made the more peculiar when one notices that the Armenians and Moslems, who live near the Kochkiri, live in well built villages with hewn stone houses. The Kochkiri tradition is that they lived on the Dersim but were driven thence by the present mountaineers. The Kochkiri are an unwarlike people who bear no arms, and are extremely submissive. The Moslems say that they are treacherous and have very little regard for human life. I am inclined to believe that many Kochkiri inhabit the little known district north of the Sivas-Zara road. I had not time to make further investigations.

The divisions of the Kochkiri are as follows :-

A. Sarolar

B. Barlolar $\}$ in the vicinity of Karajaran.

C. Garnolar

D. Ibolar. In the vicinity of Hamobad.

E. Eski Kochkiri (old). 400 families. This is a tribe near Erzinjian who the Kochkiri say has no connection with them but was driven out of the Kochkiri district by tribes Sec. E., No. 2, A, B, C, D, from which we may infer that Kochkiri is not the real name of Sec. E, No. 2, A, B, C,D.

3. Sinaminli. 2,500 families. This is a large tribe of real Shias dwelling in the vicinity of Malatia. These are true Shias and by report their dialect more nearly approaches modern Persian than that of any other of the Kurds. They are very friendly to Europeans and strangers, a fact that may have given rise to the idea that all Shias or Kizilbash are so, but I have had bitter experience to the contrary.

4. Kurejite. ? families. This sounds an unlikely name.

5. Al Khass. 500 families. There is a mountain called Al Khass, southeast of Aleppo, from which this tribe may have taken its name.

6. Kodir Zor. 600 families.

7. Kara Hassan. 300 families. This may be a Turkoman tribe; see De Guigne's Index of Names, to the Histoire des Huns.

8. Chughrishanli. 500 families. Probably sedentary.

9. Nederli. ? families.

10. Doghanli. 250 families. Nomads.

11. Dellianli. ? farnilies. A small tribe of nomads near Marash.

12. Jellikanli. ? families. Some at Van, others in the Marash plain. Latter are poor shepherds.

13. Lek Kurdi. ? families. This is a small tribe near Adana; they are said to speak Turkish. The name is familiar to Kurds on the Persian border, who say there are some in the Persian dominions.

14. Delli Kanli. 200 families. A small tribe of nomads of the Marash plain, the men are tall and well built, the women good looking. 
These people live in ordinary Kurdish tents in summer on the Taurus slopes, in winter they proceed to fixed camps about 30 miles west of Killis. The fixed camps have stone walls for the tents. This applies equally to Nos. 10, 11 and 12 , and No. $1 \mathrm{Hx}$ in section C.

15. Bellikanli. 250 families. Complete nomads. Kermanji dialect; rove about the Marash valley; no horses.

\section{SeCtion F.}

This zone is quite outside the Kurdistan proper, and represents the various forcible migrations of tribes from all parts of Kurdistan undertaken by Sultan Selim the conqueror. The catalogue will give approximate points from whence they came.

Interest is given to the matter by the following trifle which I remarked. Near Angora I met men from tribes Nos. 15 and 17, they wore a similar dress and turban, the turban being twisted in a peculiar manner. Near Erzinjian I remarked the same peculiar turban, which I had not seen elsewhere, being worn by certain Turks. I asked them what was the meaning of this head-dress, whereupon they replied that they were descendants of Janissaries who had been given lands by Sultan Selim after his conquest. A visit to the Museum of the Janissaries and reference to some prints of Sultan Selim's period showed me that this turban, which has now gone out of fashion, was the common head-dress of that day.

The reason it is worn by these two colonies is obvious. The descendants of the Janissaries were isolated from other Turks and observed the fashion of their fathers. The tribesmen in Anatolia had evidently adopted or been obliged to adopt Turkish dress soon after being exiled, but being an isolated people did not follow the changing fashions of later times.

1. Ukhchicemi. 300 families. Sedentary.

2. Urukchili. 400 families. These may be Yuruks.

*3. Milli. 20 families. A small band of shepherds I met near Osmanjik; they said they were Milli, and have evidently come from either the Dersim or Karaja Dagh.

4. Shaykh Bezeini. 120 families. Nomads living near Boiabad in Anatolia; say they were driven there from No. 3, section A, by Sultan Selim. Wear Anatolian dress and now talk Kermanji dialect.

5. Sheveli. ? families. A forcible migration from No. 71E, section A.

6. Badeli. 200 families. Sedentary branch, have settled near Yuzghat; these are now orthodox Moslems and date their conversion 70 years back. I presume a forcible migration from No. $1 \mathrm{D}$, section $\mathbf{E}$.

7. Haji Banli. 300 families. Semi-nomadic, sub-tribe of No. 1, section C. A forcible migration from the Dersim or Karaja Dagh. 
A. Khatun Oghli. 400 families. Semi-nomadic, subtribe of No. 1. section C, from Karaja Dagh. (Possibly Turkomans.)

B. Makhani. 300 families. Semi-nomadic, sub-tribe of No. 1, section C, from Karaja Dagh.

C. Omaranli. 800 families. Semi-nomadic, sub-tribe of No. 1, section C, from Karaja Dagh.

8. Barakatli. 1,000 families.

9. Tabur Oghli. 300 families. Semi-nomadic, might be Turkomans, but I was assured they were not.

10. Shaykh Bezeini. ? families. Reported to be some near Alashgerd, a migration from No. 3, section $A$.

11. Judi Kanli. 200 families. Perhaps a migration from Jebel Judi, near Shernakh.

12. Khalkani. 400 families. The name of a tribe now extinct which used to live near Rowanduz.

13. Seif Kani. 500 families. Semi-nomadic.

14. Nasurli. 600 families.

15. Tirikan. 400 families. A colony of Kurds planted north of the railway line, about 24 miles west of Angora; for origin see No. 9, section $\mathrm{B}$.

16. Atmanakin. ? families. A small section reported in tents near Angora, probably a forcible migration from No. 58, section A.

17. Zirikanli. 500 families. Near Angora, migration from No. 10, section D.

18. Janbelkli. 5,000 families. Mixed, nomads, semi-nomads and sedentary; expelled by Selim from No. $1 \mathrm{Mx}$, section C (the most westerly Kurds).

\section{Alphabetical List of Tribes.}

Abbasinli. Sec. B, 31H, p. 468.

Abu Tahir. Sec. C, 7, p. 473.

Acu. Sec. A, 23, p. 457.

Adamanli. Sec. D, 24, p. 478.

Alan. Sec. A, 16, p. 457 ; Sec. A, 76E, p. 462.

Alian. Sec. C, 15M, p. 474.

Alidinli. Sec. C, 18, p. 475 .

Alikanli. Sec. A, 62, p. 480 .

Aliki. Sec. D, 8D, p. 476 .

Al Khass. Sec. E, 5, p. 480.

Alush. Sec. C, 17, p. 475.
Arab Agha. Sec. D, 8B, p. 476.

Asdini. Sec. D, 8E, p. 476.

Ashaghi. Sec. A, 38, p. 459.

Ashmishart. Sec. B, 25, p. 467.

Atmanakin. Sec. F, 16, p. 482.

Atmanikan. Sec. A, 58, p. 460.

Azli. Sec. D, 4, p. 470 .

Badeli. Sec. A, 30, p. 458 ; Sec. D, 18, p. 478 ; Sec. E, 1D,'sp. 479 ; Sec. F, 6, p. 481.

Bakhtiarli. Sec. B, 31E, p. 468. 
Baki Khassa. Sec. A, 17, p. 457.

Balabranli. Sec. E, $1 \mathrm{~A}$ and B, p. 479.

Balashaghi. Sec. B, 31I, p. 468.

Balian. Sec. A, 56, p. 460.

Baliki. Sec. A, 27, p. 458.

Baradost. Sec. A, 33 and A, 33A, p. 458.

Barakatli. Sec. F, 8, p. 482.

Barguhan. Sec. C, 1Z, p. 471.

Barhan. Sec. C, 5, p. 473.

Barkoshan. Affil. to A, 73, p. 461.

Barlolar. Sec. E, 2B, p. 480.

Bashmanli. Sec. D, 20, p. 478.

Bazikli. Sec. D, 12, p. 477.

Bederi. Sec. B, 16, p. 464.

Behirmaz. Sec. B, 30, p. 467.

Beit-el-Khulta. Sec. C, 16D, p. 474.

Bejwan. Sec, A, 10, p. 456.

Bekiran. Sec. C, 16H, p. 474.

Bekran. Sec. B, 6, p. 464.

Beled. Sec. C, 16G, p. 474.

Bellicar. Sec. A, 67, p. 461.

Bellikan. Sec. D, 8I, p. 476.

Bellikanli. Sec. E, 15, p. 481.

Berazieh. Sec. C, 18, p. 475.

Berizanli. Sec. D, 6A, p. 476 .

Beroz. Sec. A, 76F, p. 462.

Berwari. Sec. A, 44, p. 459.

Berzan. Sec. A, 34, p. 458.

Besheri. Sec. B, 8, p. 464.

Beski. Sec. C, 1Gx, p. 472.

Beyleyan Porga. Sec. C. 1Nx, p. 472.

Bilbas. Sec. A, 22, p. 475.

Billijan. Affil. to Sec. A, 73, p. 461.

Bosikan. Sec. B, 18, p. 464.

Bubanli. Sec. B, 20B, p. 466.

Bujak. Sec. C, 1Ex, p. 472.

Bumteywit. Sec. C, 16A, p. 474.

Bunesi. Sec. C, 12, p. 473.

Chaikessen. 'Sec. C, 4, p. 473.

Chakali. Sec. C, $1 \mathrm{Jx}$, p. 472.

Chemikan. Sec. C, 1Y, p. 471.
Chiaresh. Sec. C, 1Bx, p. 472.

Chichichieh. Sec. C, 10, p. 473.

Chughrishanli. Sec. E, 8, p. 480.

Chukurli. Sec. D, 3, p. 476.

Daghbashi. Sec. C, 1 Dx, p. 472.

Dakhori. Sec. A, 54, p. 460 ; Sec. C, 11, p. 473.

Danan. Sec. C, $1 \mathrm{~A}$, p. 471.

Dasikan. Sec. C, 15L, p. 474.

Daudieh. Sec. A, 1, p. 455.

Del Mamikan. Sec. C, 15E, p. 474.

Dellianli. Sec. E, 11, p. 480.

Delli Kanli. Sec. E, 14, p. 480.

Dere. Sec. A, 43 , p. 459 .

Derejan. Sec. C. $10 \mathrm{x}$ and C, $1 \mathrm{Rx}$, p. 472.

Dersimli. Sec. B, 31, p. 467 .

Didan. Sec. C, 18, p. 475.

Dinan. Sec. C, 18, p. 475.

Doghanli. Sec. E, 10, p. 480.

Domana. Sec. C, 15F, p. 474.

Dorkan. Sec. C, 15G, p. 474.

Doshki. Sec. A, 41, and A, 41A, p. 459.

D'sdie. Sec. A, 2, p. 455.

Duderi. Sec. A, 61, p. 460.

Dudikanli. Sec. C, 1D, p. 471.

Dushi. Sec. C, 1K, p. 471.

Eimersan. Sec. C, 9, p. 473.

Eiru. Sec. A, 57, p. 460.

Elia. Sec. B, 29, p. 467 ; C, 1Q, p. 471.

El Kawat. Sec. C, 1J, p. 471.

Erikli. Sec. B, 20F, p. 466 .

Eski Kochkiri. Sec. E, 2E, p. 480.

Eutergetch. Sec. C, 1Lx, p. 472.

Ezdinan. Sec. A, 76A, p. 462.

Ferhad Ushaghi. Sec. B, 31D, p. 468.

(7arnolar. Sec. E, 2C, p. 480.

Gavdan. Sec. A, 76N, p. 462. 
Gewiji. Affil. to Sec. A, 73, p. 462.

Ghowruk. Sec. A, 19, p. 457.

Girdi. Sec. A, 7, and A, 7A, p. 456 ;

Sec. D, 14, p. 477.

Girgiri. Sec. C, $15 \mathrm{~K}$, p. 474.

Givran. Sec. A, 74 , p. 462 ; Sec. B,

31 L, p. 468 ; Sec. C, 8, p. 473.

Goyan. Sec. A, 53, p. 460.

Guran. Sec. A, 13, p. 457.

Gurus. Sec. B, 27, p. 467.

Hababa. Sec. C, 16E, p. 474.

Hafjan. Sec. A, 76Q, p. 463.

Haideranli. Sec. D, 23, p. 478.

Haji. Divn. of Sec. A, 32, p. 458.

Haji Bairam. Sec. C, 1N, p. 471.

Haji Banli. Sec. F, 7, p. 481.

Haji Manli. Sec. C, $1 \mathrm{Hx}$, p. 472.

Halaji. Sec. A, 63, p. 460.

Hamawand. Sec. A, 11, p. 456.

Hamdikan. Sec. D, 21, p. 478.

Hartushi. Sec. A, 76, p. 462.

Haruna. Sec. C, 15D, p. 474.

Hassananli. Sec. D, 6, p. 476.

Hassanekan. Sec. C, 10, p. 471.

Hasseina. Sec. A, 39, p. 459 ; Sec. A, 51, p. 460.

Hasseran. Sec. C, 6, p. 473.

Haverka. Sec. C, 15I, p. 474.

Hawatan. Sec. A, 65, p. 461.

Haweri. Sec. A, 48, p. 459.

Herki. Sec. A, 32, p. 458.

Husilieh. Sec. C, 1Ax, p. 472.

Hoshian. Sec. C, 1Fx, p. 472.

Ibolar. Sec. E, 2D, p. 480.

Isiadat. Sec. C, 1R, p. 471.

Isoli. Sec. D, 7, p. 476.

Jaff. Sec. A, 12, p. 456.

Janbekli. Sec. F, 18, p. 482.

Janbeg. Sec. C $1 \mathrm{Mx}, \mathrm{p} .472$.
Jellali. Sec. A, 42, p. 459 ; Sec. B, 14 , p. 464.

Jelli. Affil. to A, 73, p. 462.

Jellikanli. Sec. E, 12, p. 480.

Jibranli. Sec. D, 8, p. 476.

Jiriki. Sec. A, 76G, p. 462.

Judi Kanli. Sec. F, 11, p. 482.

Kalendelan. Sec. C, 1M, p. 471.

Kao. Sec. C, 1 Px, p. 472.

Karabanli. Sec. B, 31F, p. 468.

Karagetch. Sec. C, 2, p. 472.

Karagetchan. Sec. C, 18, p. 475.

Kara Hassan. Sec. E, 7, p. 480

Kassiani. Sec. C, 1 Ix, p. 472.

Kechel. Sec. B, 31B, p. 467. .

Kedak. Sec. B, 24, p. 467.

Keka. Sec. A, 66, p. 461.

Kelish. Sec. C, 1F, p. 471.

Keskoli. Sec. B, 3, p. 464.

Keyburan. Sec. B, 20A, p. 466.

Keytkan. Sec. C, 18, p. 475.

Khalajan. Sec. C, 1E, p. 471.

Khalajari. Sec. C, 1P, p. 471.

Khalkani. Sec. A, 8, p. 456 ; Sec. F, 12, p. 482.

Khani. Sec. A, 68, p. 481.

Khatun Oghli. Sec. F, 7A, p. 482.

Khawistan. Sec. A, 76K, p. 462.

Khazali. Sec. B, 15, p. 464.

Khoshnao. Sec. A, 21, p. 457.

Kialoner. Sec. A, 18, p. 457.

Kichian. Sec. A, 60, p. 460.

Kiki. Sec. C, 10, p. 473.

Kinarberosh. Affil. to A, 73, p. 461.

Kiran. Sec. C, 1C, p. 471 ; Sec. C, $16 \mathrm{~F}, \mathrm{p} .474$.

Kochkiri. Sec. E, 2, p. 479.

Kodir Zor. Sec. E, 6, p. 480.

Kohan. Sec. A, 45, p. 459.

Kulbin. Sec. B, 26, p. 467.

Kumnaresh. Sec. C, 1H, p. 471.

Kurejik. Sec. E, 4, p. 480. 
Kureshli. Sec. E, 1, p. 479.

Kurian. Sec. B, 19, p. 464.

Kusan. Sec. B, 20C, p. 466.

Kuzlichan. Sec. B, 10, p. 464; Sec. B, 31K, p. 468.

Latchin Ushaghi. Sec. B, 31J, p. 468. Lek Kurdi. Sec. E, 13, p. 480. Little Pinianishli. Sec. A, 73A, p. 462. Lolanli. Sec. D, 5, p. 476.

Ma'afan. Sec. C, 18, p. 475.

Mahalemi. Sec. C, 15C, p. 473.

Makhani. Sec. F, 7B, p. 482.

Malashigo. Sec. B, 17, p. 464.

Malkari. Sec. A, 20, p. 457 .

Mamadan. Sec. A, 76M, p. 462.

Mamagan. Sec. D, 8G, p. 477.

Mamakan. Sec. A, 26, p. 457.

Mamakanli. Sec. D, 9A, p. 477.

Mamash. Sec. A, 24, p. 457.

Mamed. Sec. A, 76D, p. 462.

Mamkhor. Sec. A, 76J, p. 462.

Mamresh. Sec. A, 76C, p. 462.

Mamund. Sec. A, 6, p. 457.

Manuranli. Sec. D, 22, p. 478.

Matmieh. Sec. C, 1X, p. 471.

Mendan. Div. of Sec. A, 32, p. 458; Sec. C, 1G, p. 471.

Mendikan. Sec. C, 16I, p. 474.

Mengor. Sec. A, 25, p. 457.

Merdis. Sec. C, $1 \mathrm{Kx}$, p. 472.

Merzigi. Sec. A, 76B, p. 462.

Meshkenli. Sec. C, 1L, p. 471.

Milan. Sec. B, 31A, p. 467.

Milli. Sec. C, 1, p. 469; Sec. F, 3, p. 481.

Mir. Sec. C, 18, p. 475.

Miran. Sec. A, 5O, p. 460.

Mirkan. Sec. C, 16B, p. 474.

Mirsinan. Sec. C, 13, p. 473.

Mirzanli. Sec. B, 31G, p. 468.

Misuri. Sec. A, 40, p. 459.
Mizidagh. Sec. C, 15N, p. 474.

Mizizakh. Sec. C, 15A, p. 473.

Modeki. Sec. B, 20, p. 465.

Moman. Sec. C, 15H, p. 474.

Motikan. Sec. B, 20, p. 466.

Mukeri. Sec. A, 71B, p. 461.

Mukhel. Sec. D, 8A, p. 476.

Mulikan. Sec. C, 1Qx, p. 472.

Musanan. Aftil. to Sec. A, 73, p. 462.

Musi. Sec. B, 12, p. 464.

Musik. Sec.IB, 1, p. 463.

Nasrian. Sec. C, 1T, p. 471

Nazurli. Sec. F, 14, p. 482.

Nederli. Sec. E, 9, p. 480.

Nirva. Sec. A, 35, p. 459.

Nuredi. Sec. A, 14, p. 457.

Okian. Sec. C, 18, p. 475.

Omaranli. Sec. F, 7C, p. 482.

Penjinan. Sec. B, 2, p. 464 ; Sec. D, 1, p. 476.

Pijan. Sec. C, 18, p. 475 .

Pinianishli. Sec. A, 73, p. 461.

Pinjari. Sec. B, 21, p. 466.

Piran. Sec. A, 15, p. 457.

Pirastini. Sec. A, 28, p. 458.

Pir Musi. Sec. B, 20G, p. 466.

Pisianli. Sec. D, 15, p. 477.

Pouran. Sec. B, 4, p. 464.

Putikanli. Sec. D, 13, p. 477.

Rashwan. Sec. D, 11, p. 477.

Reikan. Sec. A, 36, p. 459.

Reshjan. Sec. A, 47, p. 459 。

Reshkotanli. Sec. B, 7, p. 464.

Rutchaba. Sec. B, 20D, p. 466.

Salahan. Sec. C, 15J, p. 474.

Samuga. Sec. C, 16C, p. 474.

Sarmi. Sec. B, 13, p. 464.

Sarolar. Sec. E, 2A, p. 480. 
Sartan. Sec. C, 1V, p. 471.

Saur. Sec. C. 15B, p. 473.

Seidan. Sec. C, 1B, p. 471.

Seif Kani. Sec. F, 13, p. 482.

Shabak. Sec. A, 5, p. 455 .

Shadadan. Sec. C, 18, p. 475.

Shaderli. Sec. D, 8H, p. 476 ; Sec. D,

19, p. 478 ; Sec. E, 1C, p. 479.

Sharafan. Sec. A, 76L, p. 462.

Shawak. Sec. B, 31C, p. 468.

Shayk Bezeini. Sec. A, 3, p. 455 ;

Sec. D, 16, and D, 16A, p. 477 ;

See. F, 4, p. 481 ; Sec. F, 10, p. 482.

Shaykdodanli. Sec. B, 5, p. 464.

Shaykhan. Sec. A, 4, p. 455, and A,

46 , p. 459 ; Sec. C, 18 , p. 475.

Shaykhekan. Sec. D, 8F, p. 476 .

Shekak. Sec. A, 71, p. 461.

Shekifti. Sec. A, 71A, p. 461.

Shemsiki. Sec. A, 75, p. 462.

Sherkian. Sec. C, 1I, p. 471.

Shernakhli. Sec. A, 53A, p. 460.

Sheveli. Sec. A, $71 \mathrm{C}$ and A, $71 \mathrm{E}, \mathrm{p}$. 461 ; Sec. F, 5, p. 481.

Shevilan. Affil. to Sec. A, 73, p. 462.

Shidan. Sec. A, 76H, p. 462.

Shiriki. Sec. A, 55, p. 460.

Shirwan. Sec. A, 31, p. 458.

Silukan. Sec. A, 59, p. 460 ; Sec. D, 2, p. 476.

Sinaminli. Sec. E, 3, p. 481.

Sinan. Sec. B, 28, p. 467.

Sindi. Sec. A, 52, p. 460.

Sipikanli. Sec. D, 9, p. 477

Slivan. Sec. B, 22, p. 466.

Spirti. Sec. A, 49, p. 459.

Suratawan. Affil. to A, 73, p. 461.
Surchi. Sec. A, 9, p. 456.

Surkishi. Sec. C, 14, p. 473.

Tabur Oghli. Sec. F, 9, p. 482.

Takuli. Sec. A, 69, p. 461.

Tchuvan. Sec. C, 1U, p. 471.

Tirikan. Sec. B, 9, p. 464 ; Sec. F, 15, p. 482.

Tiyan. Sec. A, 64, p. 460.

Torini. Sec. D, 8C, p. 476.

Ukhchicemi. Sec. F, 1, p. 481.

Urukchili. Sec. F, 2, p. 481.

Usbakhan. Sec. C, 1W, p. 471.

Yezidis. Sec. A, 46, A, 48, p. 459 ; Sec. D, 25, p. 478.

Yezidis of the Sinjar. Sec. C, 16, p. 474.

Zazas. Sec. B, 23, p. 466 ; Sec. C, 3, p. 473.

Zebar. Sec. A, 37, p. 459.

Zedek. Sec. A, 760, p. 463.

Zefki. Sec. A, 76P, p. 463.

Zeidan. Sec. B, 20E, p. 466.

Zekeri. Sec. B, 11, p. 464.

Zemzan. Sec. A, 29, p. 458.

Zerhati. Div. of Sec. A, 32, p. 458.

Zerwan. Sec. C, 18, p. 475.

Zerzan. Sec. A, 72, p. 461.

Zeydan. Div. of Sec. A, 32, p. 458 ; affil. to Sec. A, 73, p. 461.

Zilanli. Sec. D, 17, p. 477.

Zirikanli. Sec. D, 10, p. 477 ; Sec. F, 17, p. 482.

Zirofkan. Sec. C, 1Cx, p. 472. 